\title{
Job search information behaviours: an ego-net study of networking amongst young job-seekers
}

\section{Authors}

\section{John Mowbray $^{1}$, Hazel Hall ${ }^{1}$, Robert Raeside ${ }^{2}$ and Peter J. Robertson $^{3}$}

${ }^{1}$ School of Computing, Edinburgh Napier University, Scotland, UK

${ }^{2}$ Business School, Edinburgh Napier University, Scotland, UK

${ }^{3}$ School of Applied Sciences, Edinburgh Napier University, Scotland, UK

\section{Corresponding Author:}

\section{Hazel Hall}

Edinburgh Napier University, School of Computing, 10 Colinton Road, Edinburgh, EH10 5DT, Scotland, UK

Email: $\underline{\text { h.hall@napier.ac.uk }}$

\section{Keywords}

Employment, employability, information behavior theory, job-seekers, networking, policy, social capital, social media, social network analysis, young people

\section{Abstract}

Networking is considered an integral feature of job search, yet its behavioural manifestation has received little attention in the extant literature. Here this is addressed in a study of young job-seekers that adopted an egocentric network approach underpinned by Information Behaviour theory, with specific reference to Wilson's model of information needs and seeking. The analysis of data from semi-structured interviews reveals that job-seekers acquire a broad range of job search information from contacts in their networks, and that the contributions of such contacts extend beyond the sharing of job vacancy alerts. In addition, in cases where social media platforms are accessed by job-seekers, these facilitate crucial ties to industry contacts, and provide valuable informational opportunities to those who adopt them. These findings contribute to a widened understanding of the information behaviours that support the effective mobilisation of contacts within social networks during job search, and are of particular 
Mowbray, Hall, Raeside \& Robertson (2018 in press). Job search information seeking behaviours: an ego-net study of networking amongst young job-seekers. Journal of Librarianship and Information Science.

interest to policy-makers whose remit includes the employability of the youth labour force.

\section{Introduction}

An abundance of empirical evidence has been gathered about job search across disciplines (for reviews see Manroop and Richardson, 2016; Saks, 2005; Van Hoye, et al. 2013). However, to date there has lacked a complete and micro-level understanding of the day-to-day processes of job search, including the challenges faced by job-seekers, and the specific sources of information that they use (Wanberg, 2012: 389; Van Hoye et al., 2013: 15). Informed by Information Behaviour theory developed by Tom Wilson (1981; 1997), the research outlined in this paper addresses this gap in knowledge through the analysis of a set of egocentric networks of young job-seekers. Specifically, it explores the role of job search networking as an information behaviour, and how social media platforms such as Facebook and Twitter feature in this process.

The findings discussed below reveal the key informational role of network contacts in job-seeking as one that extends beyond the simple diffusion of information about employment opportunities. By drawing particular attention to the influence of context and needs on networking behaviours, this adds to prior work that has identified the operational role of social capital as a determinant of early success in the labour market (Caspi et al., 1998; Kramarz and Skans, 2014). Consideration of these themes with direct reference to Information Behaviour theory indicates that policy interventions designed to improve networking and the use of social media have to take into account a range of factors such as job search goals, employment status, work experience, perceptions and attitudes. This study is an important contribution since the ability to use social networks effectively during job search is considered a key facet of employability (McQuaid and Lindsay, 2005: 210), and viewed as integral to career management by policy makers at the national level (Skills Development Scotland, 2012: 7).

\section{Literature review}

Previous studies of job search have highlighted the importance of quality information sources to the determination of employment outcomes (Schwab et al., 1987; Wanberg, 2012). To this end, job search information sources have often been conceptualised as either formal or informal in nature (Huffman and Torres, 2001; Saks, 2005). The former are considered to be the use of employment agencies or job search databases, whereas the latter are described as the use of personal contacts such as friends, family members, or work contacts. The use of such contacts is referred to as 'networking' behaviour, and has been recognised as a prerequisite of a high-quality job search (Van Hooft et al., 2012: 9).

The proficiency of such social contacts in relaying job opportunities which lead to employment has been demonstrated by studies of labour markets throughout the world. 
Mowbray, Hall, Raeside \& Robertson (2018 in press). Job search information seeking behaviours: an ego-net study of networking amongst young job-seekers. Journal of Librarianship and Information Science.

For example, Granovetter (1995: 140-141) compiled a list of surveys from countries such as Japan, the Netherlands, the USA, and the UK, which showed that a range of $25-75 \%$ of employed people in these respective labour markets had found out about their job from a network contact. More recently, Franzen and Hangartner (2006: 357) found a similar variation in a study of 27 different countries, with the figure for the UK being just under a third at $31.0 \%$. The variations can be explained by a wide range of cultural, economic, and social factors. For example, differences can be created between highly centralised state-socialist countries where jobs are mostly assigned to candidates, and in countries where candidates are matched to jobs through the market (Bian, 1997; Tian and Lin, 2016). However, it is clear that social contacts play a considerable role in the allocation of labour worldwide.

The informational role of contacts in employment outcomes can be partially explained by the structure of an individual's social network. For example, some studies have found that 'weak' network contacts, or acquaintances, are the most prolific in terms of the allocation of labour (Granovetter, 1995; Yakubovich, 2005). It has been posited that this is because weaker network ties are more likely to reach into the wider social system and therefore to facilitate the acquisition of novel information about jobs (Granovetter, 1973; 1983). However, there is also empirical evidence that suggests that strong network contacts are the most effective in certain labour market contexts (Bian, 1997; Franzen and Hangartner, 2006; Watanabe, 1997), leading to speculation that the trust and obligation within such relationships is an influential factor in the job search process (Bian, 1997; Granovetter, 1983).

Equally important to network structure is the presence of social capital, as related to the quality of the resources contained within networks (Lin, 1999; 2002; 2008). From the micro-level perspective, Portes (2000: 6) asserts that social capital is embodied by the contacts within individuals' networks from whom resources such as information can be acquired. Previous studies indicate that labour market outcomes are associated with access to differing levels of social capital, such as a higher proportion of contacts within occupationally prestigious positions (De Graaf and Flap, 1998; Gayen et al., 2010; Lin et al., 1981; Macmillan et al., 2015; Russell, 1999; Seibert et al., 2001). For younger people, such social capital can be embedded in their networks by providing them with exposure to workplace learning and work-related learning content - with substantial employer engagement - whilst at school (Mann, 2012). However, these studies focus purely on accessible rather than mobilised resources (Lin, 1999). Therefore the functional role of information in achieving these ends is assumed and not explicit.

In contrast, studies of job search networking within the field of Psychology do focus on the mobilisation of network resources. They highlight the role of various antecedents to networking during job search, such as conscientiousness, extraversion, networking comfort, and possession of a larger social network with more strong ties (Lambert et al., 2006; Van Hoye et al., 2009; Wanberg et al, 2000). It has also been argued that engagement in job search networking leads to more job offers and quicker reemployment following redundancy (Van Hoye et al., 2009; Wanberg et al., 2000). However, these studies lack theoretical grounding, and take a purely quantitative 
approach. Furthermore, they do not factor in the role of digital technologies such as social media platforms. Qualitative studies of information seeking within other contexts (e.g. the information behaviour of academics) have found networking to be a crucial and nuanced set of behaviours, which are aided significantly by increased Internet access (Foster, 2005; Meho and Tibbo, 2003).

Social media platforms such as Facebook can provide access to valuable social capital for users (Ellison et al., 2007; Valenzuela et al., 2009). It has also been found that social media are used by a majority of job-seekers in the UK (Adecco, 2014), although how they are appropriated to acquire job search information is unclear. Despite this, information behaviour research indicates that there are personality differences between those who seek information on platforms such as Facebook and Twitter (Hughes et al., 2012). This could be attributed to their respective functionalities, which invite differing levels of content and identity sharing, amongst other dynamics (El Ouiridi et al., 2014; Kietzmann et al., 2011). To this end, whilst both can be used for multiple purposes, it has been argued that one lends itself more to reciprocal social exchange (Facebook), and the other is deployed for the sharing of information and opinions (Twitter) (Huberman et al., 2009; Kwak et al., 2010; Mo and Leung, 2014).

Prominent contributors within the field of careers guidance research have emphasised the importance of developing 'digital career literacy' skills, which include the appropriation of social media platforms such as Facebook, Twitter, and LinkedIn to build and use networks (Hooley, 2012; Hooley et al., 2010; Longridge et al., 2012). During a career development intervention, it has been shown that young people are able to create opportunities for themselves by appropriating social media, and learn to think of them as useful career tools (Longridge et al., 2012: 3). However, it has also been found that young people are not predisposed to using digital platforms for careers activities, and lack the relevant knowledge of how to use them for such functional purposes (Longridge et al., 2013; Papakonstantinidis, 2014; Rutten et al., 2016). Despite these interesting insights, it has been recognised that there exists comparatively little research in the careers literature testing the efficacy of networking in relation to other aspects of employability (Artess et al., 2017: 25).

\section{Study purpose, objectives, and the egocentric network approach}

As shown above, there is a broad consensus in the extant literature that network contacts, social capital, job search networking, and social media platforms each have a considerable - and often interlinked - impact on the job search process. However, beyond the intersection where information about a job opening is passed on and leads to eventual employment (see for example, Franzen and Hangartner, 2006; Granovetter, 1974), little is known about how networks relay information throughout job search. The purpose of the study reported here, therefore, was to elucidate the role of informational transactions between network entities throughout job search by adopting an egocentric network approach. 
Mowbray, Hall, Raeside \& Robertson (2018 in press). Job search information seeking behaviours: an ego-net study of networking amongst young job-seekers. Journal of Librarianship and Information Science.

Egocentric networks are part of Social Network Analysis (SNA) research, and focus on the ties of individuals with their personal networks of contacts (Robins, 2015: 20). The conceptualisation of ties as flows of non-material goods such as information is a common feature of SNA research (Wasserman and Faust, 1994: 51), and has been applied to a number of studies within the domain of Information Science (e.g. Alam, Khusro, Ullah and Karim, 2017; Cooke and Hall, 2013; Hosseini-Pozveh, Zamanifar and Naghsh-Nilchi, 2016; and a review paper by Schultz-Jones, 2009). SNA was deployed in the current study to gain a micro-level understanding of how young job-seekers interact with network entities to acquire job search information. Therefore, only mobilised social capital was considered, as opposed to potentially accessible capital (Lin, 1999).

\section{Method}

\section{Sample choice and description}

This study was undertaken in Scotland. Maximum variation sampling (Palys, 2008: 697) was adopted to recruit participants. The young people sought could be considered both typical and non-typical job-seekers within the Scottish youth labour market, to thus cover a broad spectrum of job search networking experiences. Seven participants were recruited ${ }^{i}$ on the basis that they were engaged in a job search, or were recently employed following a sustained period of job searching. Efforts were also made to ensure that the participants came from different areas of the country and had varying educational attainment levels and employment statuses. The latter was guided by the Scottish Government's 'Destinations of School Leavers' framework (Scottish Government, 2017). Details of the sample can be seen in Table $1^{\text {ii }}$.

\begin{tabular}{|l|l|l|l|l|l|l|}
\hline Name & Age & Gender & $\begin{array}{l}\text { Local } \\
\text { authority area }\end{array}$ & Education & $\begin{array}{l}\text { Job search } \\
\text { status }\end{array}$ & $\begin{array}{l}\text { Employment } \\
\text { status }\end{array}$ \\
\hline Ashley & 17 & Female & East Lothian & $\begin{array}{l}\text { No } \\
\text { qualifications }\end{array}$ & $\begin{array}{l}\text { Actively } \\
\text { searching }\end{array}$ & $\begin{array}{l}\text { Activity } \\
\text { agreement }\end{array}$ \\
\hline Craig & 17 & Male & Edinburgh & $\begin{array}{l}\text { No } \\
\text { qualifications }\end{array}$ & $\begin{array}{l}\text { Actively } \\
\text { searching }\end{array}$ & $\begin{array}{l}\text { Activity } \\
\text { agreement }\end{array}$ \\
\hline Michael & 17 & Male & Moray & Scottish NQs & $\begin{array}{l}\text { Actively } \\
\text { searching }\end{array}$ & Unemployed \\
\hline
\end{tabular}


Mowbray, Hall, Raeside \& Robertson (2018 in press). Job search information seeking behaviours: an ego-net study of networking amongst young job-seekers. Journal of Librarianship and Information Science.

\begin{tabular}{|l|l|l|l|l|l|l|}
\hline Name & Age & Gender & $\begin{array}{l}\text { Local } \\
\text { authority area }\end{array}$ & Education & $\begin{array}{l}\text { Job search } \\
\text { status }\end{array}$ & $\begin{array}{l}\text { Employment } \\
\text { status }\end{array}$ \\
\hline Ross & 19 & Male & Fife & HND & $\begin{array}{l}\text { Actively } \\
\text { searching }\end{array}$ & $\begin{array}{l}\text { Full-time } \\
\text { student }\end{array}$ \\
\hline Steve & 20 & Male & Fife & HND & $\begin{array}{l}\text { Actively } \\
\text { searching }\end{array}$ & $\begin{array}{l}\text { Full-time } \\
\text { student }\end{array}$ \\
\hline Simon & 23 & Male & Renfrewshire & MSc & $\begin{array}{l}\text { Recently } \\
\text { employed }\end{array}$ & Employed \\
\hline Suzanne & 24 & Female & Glasgow & MSc & $\begin{array}{l}\text { Actively } \\
\text { searching }\end{array}$ & Employed \\
\hline
\end{tabular}

Table 1: Sample details

\section{Interview design}

Interviews were conducted in February and March 2016 to gather qualitative data. They were semi-structured to encourage the participants to expand upon their answers where necessary (Barriball and While, 1994: 330). The questions were informed by Wilson's information needs and seeking model, which is distinguished by its individuallevel focus (1981: 6). As Wilson (1999: 253) indicates, the model is not comprehensive, but can stimulate thinking "about the kinds of elements that a more complete model ought to include", and as a means to generate hypotheses. In the current study it was used to stimulate thinking about job search networking as an information behaviour, and to generate variables to be included in a survey questionnaire (implemented in a later phase of the larger study to which this research contributes). This is a common approach in mixed method research (Cresswell and Clark, 2006: 59).

As shown in Figure 1, Wilson's model has three key components: (i) context of information need; (ii) intervening variables; and, (iii) information-seeking behaviour. 
Mowbray, Hall, Raeside \& Robertson (2018 in press). Job search information seeking behaviours: an ego-net study of networking amongst young job-seekers. Journal of Librarianship and Information Science.

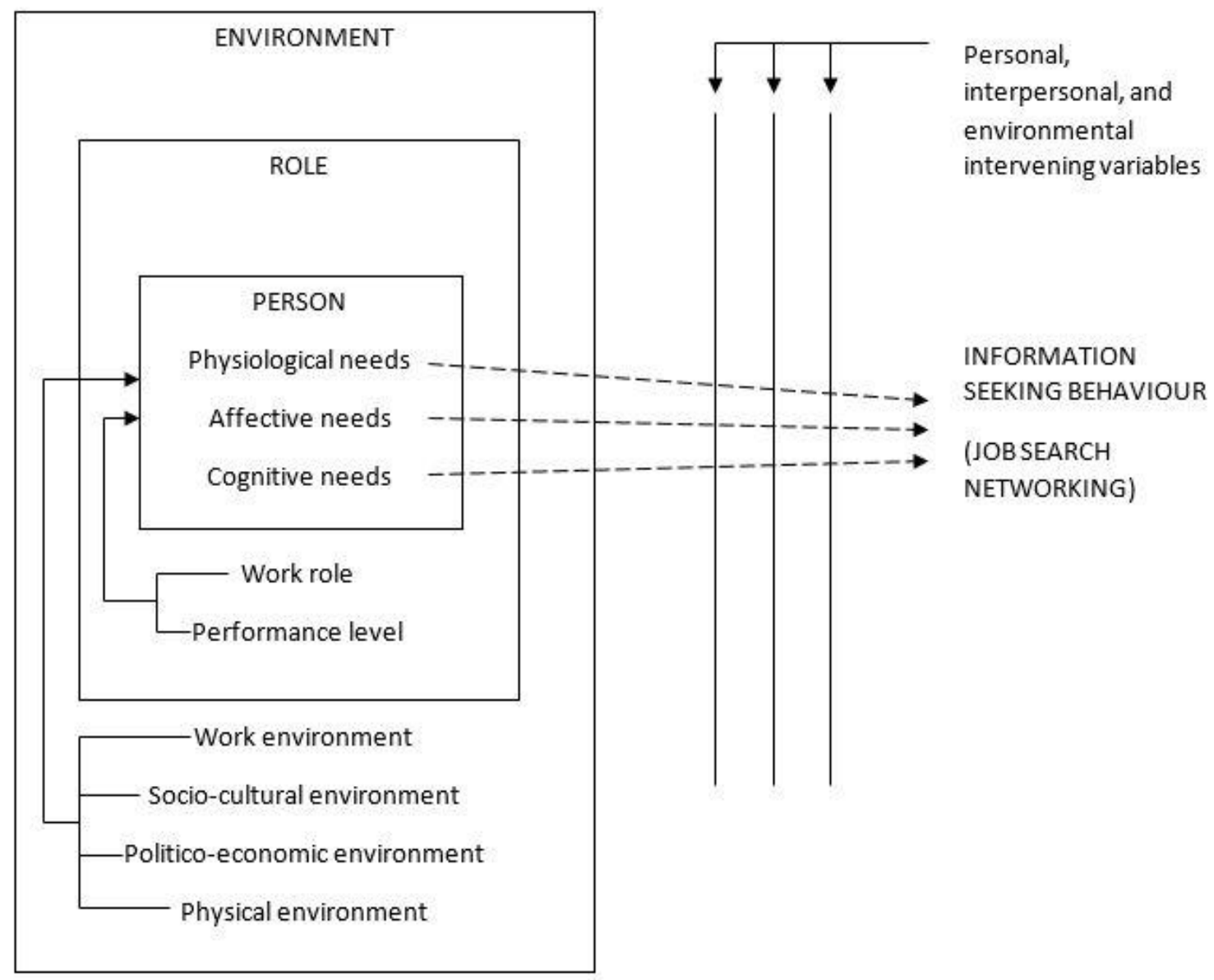

Figure 1: An adaptation of Wilson's information needs and seeking model (1981, p.6)

Wilson (1981) emphasises the importance of studying the information needs of individuals to develop an understanding of their behaviour. This involves establishing the basic need (e.g. physiological need) which motivates them to seek information, and the various contexts (i.e. social role, environmental) within which these needs develop. For this study these factors were adapted and incorporated into the series of semi-structured questions about job search. For example, the participants were asked to explain their motivations for seeking a job (i.e. personal), their employment status and the nature of their job search (i.e. social role), and how they used social media platforms (i.e. environmental). Wilson (1997: 556) also asserts that the perception of an information need does not always provide sufficient impetus for information seeking behaviour, and that needs can be tempered by various intervening variables. Probing questions were used throughout the interviews to uncover any potential barriers to information seeking that the participants faced in cases when this was not made explicit in the initial responses given.

An egocentric network approach called the "name-generator" was used to gather data specifically about job search networking (Robins, 2014: 103-107). This involved 
asking the ego in the network (i.e. the participant/job-seeker) to relate any alters (i.e. people and organisations) who had provided him/her with information relating to job search since they had undertaken their search for employment. The participants were prompted with a number of potential types of information, such as job opportunities, assistance with applications, or general advice relevant to job search. Where necessary, the participants were probed for details about these informational exchanges, to determine (i) the nature of the contact, and (ii) the type of information acquired, and (iii) how it was transmitted (e.g. face-to-face or via a social media platform).

\section{Data analysis}

The data were subjected to directed content analysis as a technique that can be used to "validate or extend a theoretical framework" (Hsieh and Shannon: 1281). To determine the validity of his theoretical framework within the context of job search networking, the transcripts from the interviews were coded and organised into themes based upon Wilson's information needs and seeking model (Figure 1). Data pertaining to the participants' ego-nets were also quantified and input manually to UciNet6 (a popular Social Network Analysis package) (Borgatti et al., 2002). Visual representations of the networks were created with Netdraw. These visual outputs have been labelled 'job search information networks' (JSINs) in the remainder of the paper to emphasise the focus on informational exchange during the job search process. The nodes (which represent network contacts in the JSINs) are allocated different shades and shapes depending on the medium for information exchange and the nature of the contacts respectively. More details about the JSINs are provided below.

\section{Findings}

\section{Job search information types}

At the time of the study the participants sourced a variety of information types from their JSINs. These have been coded to five key categories: (i) personal development; (ii) industry and role related; (iii) practical skills; (iv) contacts and leads; and (v) job opportunities. Personal development information relates to the delineation of an overall job search goal. Ashley, for example, spoke about an exercise in which she was helped to "make a big mind map of past and present" to outline previous work experience and hobbies. This helped her create a narrative for her career progression, and understand the type of jobs that were within her capabilities. Industry and role related information is research-based, and relates to the undertakings of companies within specific industries, or specific role requirements of certain jobs. Information about practical skills concerns tasks such as creating CVs or preparing for interviews. Contact and leads information refers to the other potential contacts who could assist the jobseekers. Finally, job opportunities relates to the acquisition of information about specific job openings. 
Mowbray, Hall, Raeside \& Robertson (2018 in press). Job search information seeking behaviours: an ego-net study of networking amongst young job-seekers. Journal of Librarianship and Information Science.

\section{Network measures, contextual factors, and job search information networks}

Table 2 displays some simple network measures related to each of the participants' JSINs, organised in descending order by number of contacts. The degree proportions show how many times the participants passively (in-degree) or actively (outdegree) acquired information from contacts (please see Table 3 for more information on in-degree and out-degree tie directions). This indicates that, for example, Suzanne (100\% out-degree) was a very active networker during job search, compared with Steve ( $0 \%$ outdegree). It also shows the proportion of formal or informal contacts within each JSIN, and the proportion of these contacts with whom there was a social media exchange of job search information. These figures indicate that social media had a significant bearing, where used. For example, Ross and Michael both had high proportions of social media contacts, and correspondingly high numbers of contacts. For Steve, the removal of social media would render him in possession of a solitary contact. These figures and concepts will be discussed further below.

\begin{tabular}{|l|l|l|l|l|l|l|l|}
\hline $\begin{array}{l}\text { Participants } \\
\text { (length of } \\
\text { search) }\end{array}$ & $\begin{array}{l}\text { No. of } \\
\text { contacts } \\
(\mathrm{n})\end{array}$ & $\begin{array}{l}\text { In- } \\
\text { Degree } \\
(\%)\end{array}$ & $\begin{array}{l}\text { Out- } \\
\text { Degree } \\
(\%)\end{array}$ & $\begin{array}{l}\text { Formal } \\
(\%)\end{array}$ & $\begin{array}{l}\text { Informal } \\
(\%)\end{array}$ & $\begin{array}{l}\text { Non- } \\
\text { social } \\
\text { media } \\
(\%)\end{array}$ & $\begin{array}{l}\text { Social } \\
\text { media } \\
(\%)\end{array}$ \\
\hline $\begin{array}{l}\text { Ross } \\
(3 \text { months })\end{array}$ & 19 & $16 \%$ & $89 \%$ & $68 \%$ & $37 \%$ & $26 \%$ & $79 \%$ \\
\hline $\begin{array}{l}\text { Michael } \\
(3 \text { months })\end{array}$ & 14 & $50 \%$ & $79 \%$ & $57 \%$ & $63 \%$ & $71 \%$ & $57 \%$ \\
\hline $\begin{array}{l}\text { Simon } \\
(6 \text { months })\end{array}$ & 11 & $55 \%$ & $82 \%$ & $73 \%$ & $27 \%$ & $82 \%$ & $27 \%$ \\
\hline $\begin{array}{l}\text { Ashley } \\
(7 \text { months })\end{array}$ & 9 & $89 \%$ & $44 \%$ & $89 \%$ & $11 \%$ & $100 \%$ & $0 \%$ \\
\hline $\begin{array}{l}\text { Suzanne } \\
(1 \text { month) }\end{array}$ & 9 & $0 \%$ & $100 \%$ & $78 \%$ & $22 \%$ & $89 \%$ & $22 \%$ \\
\hline
\end{tabular}


Mowbray, Hall, Raeside \& Robertson (2018 in press). Job search information seeking behaviours: an ego-net study of networking amongst young job-seekers. Journal of Librarianship and Information Science.

\begin{tabular}{|l|l|l|l|l|l|l|l|}
\hline $\begin{array}{l}\text { Participants } \\
\text { (length of } \\
\text { search) }\end{array}$ & $\begin{array}{l}\text { No. of } \\
\text { contacts } \\
(\mathrm{n})\end{array}$ & $\begin{array}{l}\text { In- } \\
\text { Degree } \\
(\%)\end{array}$ & $\begin{array}{l}\text { Out- } \\
\text { Degree } \\
(\%)\end{array}$ & $\begin{array}{l}\text { Formal } \\
(\%)\end{array}$ & $\begin{array}{l}\text { Informal } \\
(\%)\end{array}$ & $\begin{array}{l}\text { Non- } \\
\text { social } \\
\text { media } \\
(\%)\end{array}$ & $\begin{array}{l}\text { Social } \\
\text { media } \\
(\%)\end{array}$ \\
\hline $\begin{array}{l}\text { Craig } \\
(2 \text { months })\end{array}$ & 4 & $100 \%$ & $25 \%$ & $100 \%$ & $0 \%$ & $100 \%$ & $0 \%$ \\
\hline $\begin{array}{l}\text { Steve } \\
(3 \text { months })\end{array}$ & 4 & $100 \%$ & $0 \%$ & $50 \%$ & $50 \%$ & $25 \%$ & $75 \%$ \\
\hline
\end{tabular}

Table 2: Job search information network measures

The context of the participants' job searches are presented below alongside their respective JSIN diagrams. The JSINs are then used as a basis to analyse the networking behaviours of the young job-seekers. Given the multilevel nature of the networks, the different characteristics of the JSINs have been denoted by a variety of symbols. These are presented in Table 3.

\begin{tabular}{|c|c|c|}
\hline Node shade & Node shape & Tie direction \\
\hline $\begin{array}{l}\text { Grey: non-social } \\
\text { media information } \\
\text { exchange } \\
\text { White: social media } \\
\text { information exchange } \\
\text { White with cross: } \\
\begin{array}{l}\text { social media and non- } \\
\text { social media } \\
\text { information exchange }\end{array}\end{array}$ & $\begin{array}{l}\text { Upwards triangle: } \\
\text { participant/job-seeker } \\
\text { Circle: informal contact } \\
\text { Square: formal contact } \\
\text { Downwards triangle: informal } \\
\text { and formal contact }\end{array}$ & $\begin{array}{l}\text { Out-degree (i.e. arrow } \\
\text { pointing from ego to } \\
\text { contacts): jobseeker has } \\
\text { mobilised contact for } \\
\text { information } \\
\text { In-degree (i.e. arrow } \\
\text { pointing from contacts to } \\
\text { ego): contact has mobilised on } \\
\text { behalf of the jobseeker } \\
\text { Out/in-degree (i.e. arrow } \\
\text { pointing both ways, from ego } \\
\text { to contacts and from } \\
\text { contacts to ego): jobseeker } \\
\text { has mobilised contact for } \\
\text { information, and the contact } \\
\text { has mobilised on the } \\
\text { jobseekers behalf with } \\
\text { information, separately }\end{array}$ \\
\hline
\end{tabular}

Table 3: JSIN symbols 


\section{Ashley's job search information network}

Ashley was on an "activity agreement" in early 2016, i.e. she was receiving support to help her prepare for education, training, or employment (Scottish Government, 2017). She lived estranged from her family in a youth hostel at the time of interview, and had been actively seeking work for around seven months. Her overall job search goal was to find full-time employment in an administrative role. She was motived to find a job to develop some routine in her life, and for financial reasons. She said, "I actually live in a hostel so I have to pay for everything myself. I need more money”.

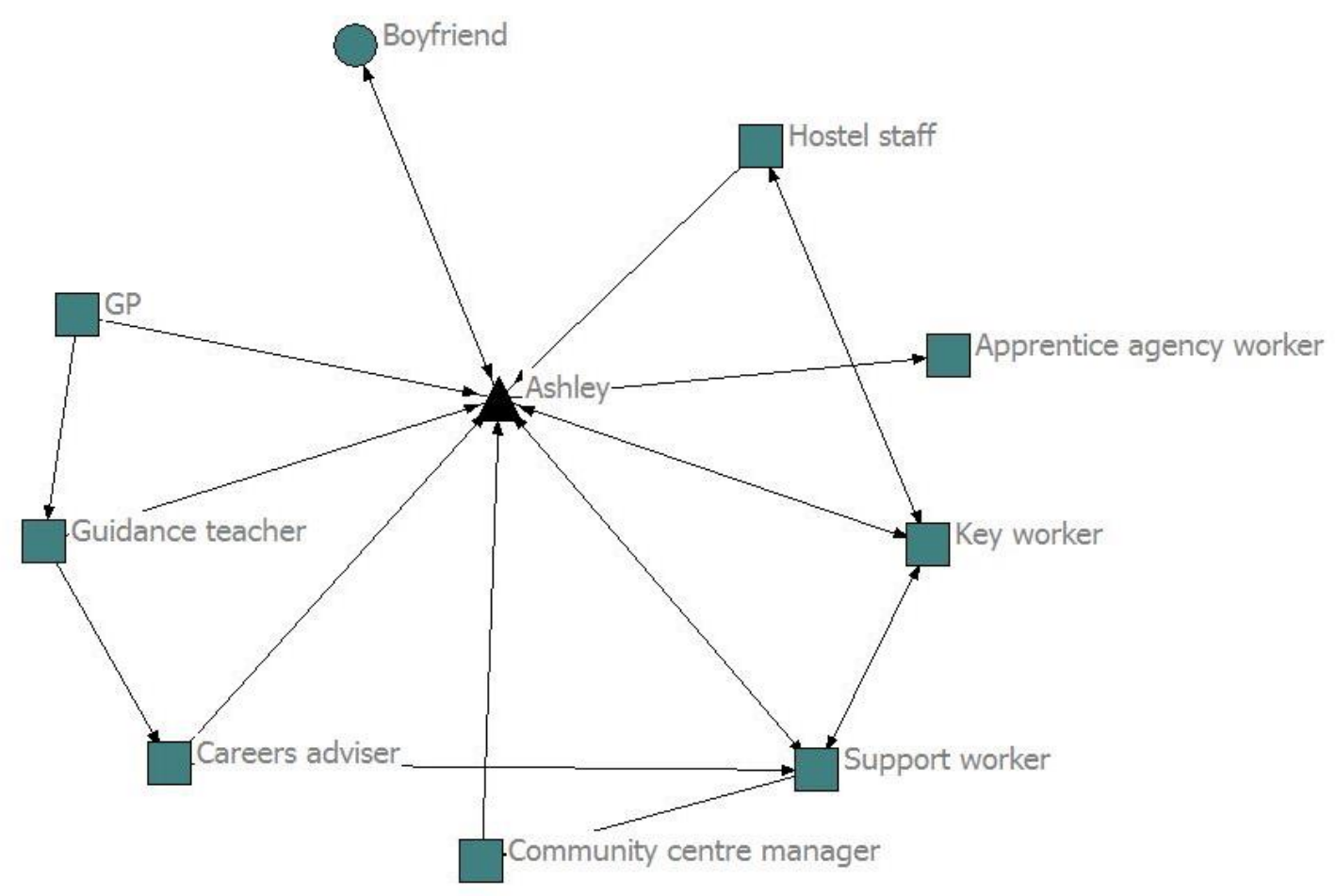

Figure 2 Ashley's job search information network

As shown in Figure 2, Ashley had a high proportion of contacts who were indegree $(89 \%)$ and formal (89\%). Indeed, many of these contacts were interconnected, illustrating a period whereby organisations and formal individuals had acted on Ashley's behalf to assist her into employment. It is notable that the careers service (Skills Development Scotland) was integral to this process, with the contact 'Careers adviser' having had several meetings with Ashley before directing her towards an employability group run by a charitable enterprise. This group is one of several working in partnership with the careers service to assist young people who face barriers to the labour market in Scotland. The leader of the group ('Support worker') had been influential in her job search, and had helped Ashley secure an interview with a local community centre 
Mowbray, Hall, Raeside \& Robertson (2018 in press). Job search information seeking behaviours: an ego-net study of networking amongst young job-seekers. Journal of Librarianship and Information Science.

manager for an administration internship. Ashley noted the help she had received. She explained: "It was other people around me helping. I didn't find out about it". A full typology of contacts and information contained within Ashley's JSIN is presented in Table 4.

\begin{tabular}{|c|c|c|}
\hline Nature of contact & Contact type & $\begin{array}{l}\text { Type of information provided } \\
\text { (by no. of contacts) }\end{array}$ \\
\hline Formal Individual & $\begin{array}{l}\text { Industry and business } \\
\text { representatives: Community } \\
\text { centre manager, Apprentice } \\
\text { agency worker } \\
\text { Support workers and careers } \\
\text { advisers: Support worker, Key } \\
\text { worker, Careers adviser } \\
\text { Teachers and tutors: Guidance } \\
\text { teacher } \\
\text { Other formal individuals: GP }\end{array}$ & $\begin{array}{l}\text { Personal development (2) } \\
\text { Industry/role-related (2) } \\
\text { Practical skills (2) } \\
\text { Contacts/leads (4) } \\
\text { Job opportunities (3) }\end{array}$ \\
\hline Formal organisation & Public bodies and charities: & $\begin{array}{l}\text { Personal development (1) } \\
\text { Practical skills (1) }\end{array}$ \\
\hline Informal & $\begin{array}{l}\text { Extended family, friends, and } \\
\text { classmates: Boyfriend }\end{array}$ & $\begin{array}{l}\text { Personal development (1) } \\
\text { Practical skills (1) }\end{array}$ \\
\hline
\end{tabular}

Table 4 Analysis of Ashley's JSIN

\section{Craig's job search information network}

Craig was also on an activity agreement, and at the time of interview had been actively looking for work for two months whilst living at home with his mother. His job search goal was ill-defined. He stated that he would take "anything, really", whether parttime or full-time. His key motivator was to earn some extra money. However, he noted that this need was not pressing, citing a modest inheritance and job-seeker's allowance which gave him "enough to get on with".

Craig's lack of direction is reflected in his JSIN (Figure 3), which contains only four formal contacts. Like Ashley, these contacts were also interconnected, indicating a sequence whereby organisations, including the careers service, had mobilised on his behalf to precipitate a period of networking. Craig explained: 
Mowbray, Hall, Raeside \& Robertson (2018 in press). Job search information seeking behaviours: an ego-net study of networking amongst young job-seekers. Journal of Librarianship and Information Science.

"(After school) I went to a place called ['community group']. Once I told them that I was wanting a job they got me in touch with a Skills Development Scotland worker, and she came and talked to me a few times, and then we got in touch with ['Support worker']".

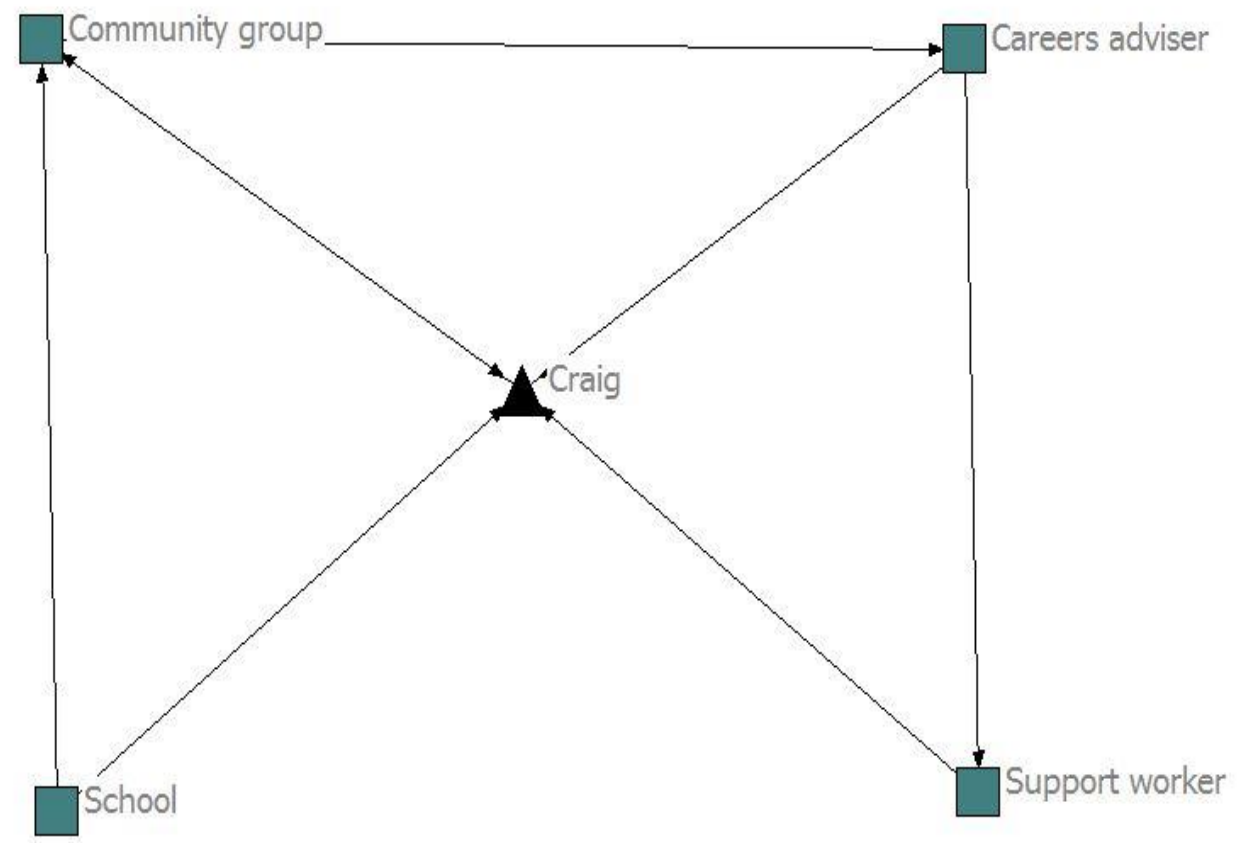

Figure 3 Craig's job search information network

Craig conducted all his job searching twice a week at the employability group run by his support worker. The lack of out-degree ties in Figure 3 illustrates his lack of active job search networking. It is also notable that none of his information exchanges happened on social media. When asked if he had ever seen job search related information whilst using social media he replied "I don't really pay attention to that stuff". A full typology of contacts and information contained within Craig's JSIN is presented in Table 5. 
Mowbray, Hall, Raeside \& Robertson (2018 in press). Job search information seeking behaviours: an ego-net study of networking amongst young job-seekers. Journal of Librarianship and Information Science.

\begin{tabular}{|l|l|l|}
\hline Nature of contact & Contact type & $\begin{array}{l}\text { Type of information provided } \\
\text { (by no. of contacts) }\end{array}$ \\
\hline Formal Individual & $\begin{array}{l}\frac{\text { Support workers and careers }}{\text { advisers: Support worker, Careers }} \\
\text { adviser }\end{array}$ & $\begin{array}{l}\text { Personal development (2) } \\
\text { Practical skills (1) } \\
\text { Contacts/leads (1) } \\
\text { Job opportunities (1) }\end{array}$ \\
Formal organisation & $\begin{array}{l}\text { Public bodies and charities: } \\
\text { Community group, School }\end{array}$ & $\begin{array}{l}\text { Personal development (1) } \\
\text { Contacts/leads (2) }\end{array}$ \\
\hline
\end{tabular}

Table 5 Analysis of Craig's JSIN

\section{Michael's job search information network}

Michael was unemployed, lived at home with his mother, and had been actively seeking a job for around three months at the time of interview. His main job search goal was to find employment as an apprentice mechanic, and he articulated a number of job search motivations:

"I don't like sitting around doing nothing. I really just want to be out working. Plus it's great just to have your own income. I feel bad in a sense as well, being there and having to rely on my mum. Also, another thing. I just got a car, so I really need money just to start lessons".

Michael's determination is reflected in the diversity of his JSIN (see Figure 4) and high proportion of out-degree contacts $(73 \%)$. His careers adviser (also with the national careers service) was a prominent contact. He met with her every two weeks for in-depth careers information. She also suggested that he follow the careers service's Facebook page, and use other social media pages to find job search information. Heeding this advice, he followed two Twitter accounts that posted local job openings (i.e. 'Local jobs Twitter 1/2)') and joined job search forums. He stated that he found "most of the jobs" that he had applied for on the careers service's Facebook page, and indicated that searching on social media dovetailed with his use of digital platforms for socialising:

"They tend to intertwine in that sense. I mean if I'm on speaking to friends, as you do for that sort of social media, there's nothing stopping me spending 5, 10 minutes just looking at these sites you know. I just use them for both. Mainly just to keep in contact with friends, obviously". 
Mowbray, Hall, Raeside \& Robertson (2018 in press). Job search information seeking behaviours: an ego-net study of networking amongst young job-seekers. Journal of Librarianship and Information Science.

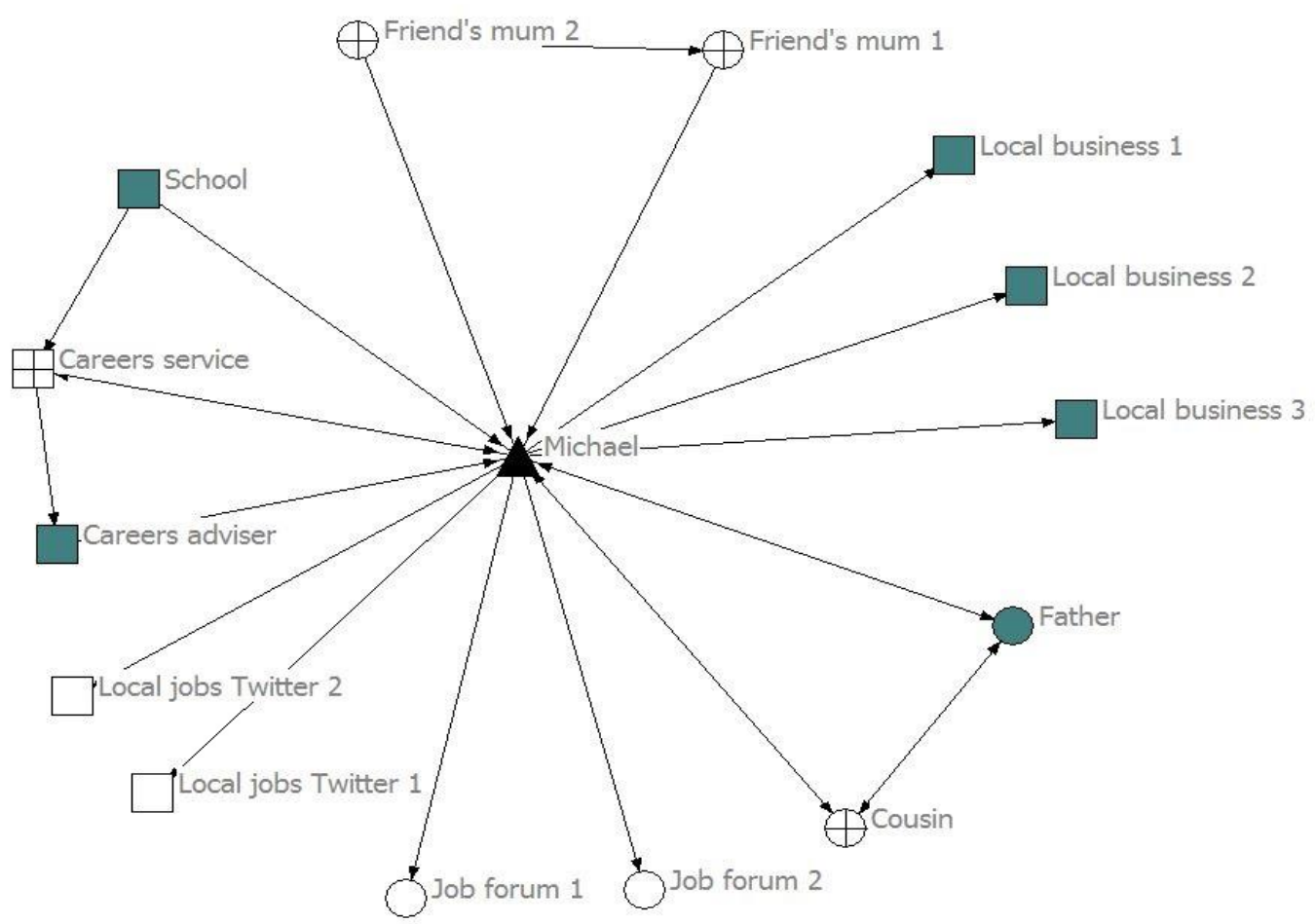

Figure 4 Michael's job search information network

'Friend's mum 1' and 'Friend's mum 2' told him about job openings when he saw them in person. They also sent him messages with job advertisements via the Facebook messenger function. Encouraged by his careers adviser, he also visited various local businesses to ask directly about jobs. A full typology of contacts and information contained within Michael's JSIN is presented in Table 6.

\begin{tabular}{|l|l|l|}
\hline Nature of contact & Contact type & $\begin{array}{l}\text { Type of information provided } \\
\text { (by no. of contacts) }\end{array}$ \\
\hline Formal Individual & $\begin{array}{l}\text { Support workers and careers } \\
\text { advisers: Careers adviser }\end{array}$ & $\begin{array}{l}\text { Personal development (1) } \\
\text { Industry/role-related (1) } \\
\text { Practical skills (1) } \\
\text { Contacts/leads (1) } \\
\text { Job opportunities (1) }\end{array}$ \\
\hline
\end{tabular}


Mowbray, Hall, Raeside \& Robertson (2018 in press). Job search information seeking behaviours: an ego-net study of networking amongst young job-seekers. Journal of Librarianship and Information Science.

\begin{tabular}{|c|c|c|}
\hline Nature of contact & Contact type & $\begin{array}{l}\text { Type of information provided } \\
\text { (by no. of contacts) }\end{array}$ \\
\hline Formal organisation & $\begin{array}{l}\text { Public bodies and charities: } \\
\text { Careers service, School } \\
\text { Private bodies and quangos: } \\
\text { Local jobs Twitter 1, Local jobs } \\
\text { Twitter } 2 \\
\text { Industry and company: Local } \\
\begin{array}{l}\text { business 1, Local business 2, Local } \\
\text { business } 3\end{array}\end{array}$ & $\begin{array}{l}\text { Personal development (1) } \\
\text { Contacts/leads (2) } \\
\text { Job opportunities (6) }\end{array}$ \\
\hline Informal & $\begin{array}{l}\text { Immediate family: Dad } \\
\text { Extended family, friends, and } \\
\text { classmates: Cousin } \\
\text { Other informal: Friends mum 1, } \\
\text { Friends mum 2, Job search forum } \\
\text { 1, Job search forum } 2\end{array}$ & $\begin{array}{l}\text { Industry/role related (2) } \\
\text { Practical skills (4) } \\
\text { Job opportunities (4) }\end{array}$ \\
\hline
\end{tabular}

Table 6 Analysis of Michael's JSIN

\section{Ross's job search information network}

Ross was a student at a Further Education college at the time of interview, and had been engaged in job search activities for around three months whilst living at home with his parents. Hoping to attend university the following year, his job search efforts were aimed at finding a summer job. To this end, his goals were multi-level:

“There's been two types of jobs I've been looking at. I've been looking at jobs specific to what I want to do in the future, like after uni. So that would be like junior games designers and all that. And then there's been just like the jobs that I need to make money out of or whatever. You know, any old type of job, basically".

He displayed a level of conscientiousness in his motivations for finding work. For example, he said "If you don't have experience, you will struggle to get a job in the software industry." However, he also needed to save money in case he was offered a place at university, and this spurred his search for a back-up option. 
Mowbray, Hall, Raeside \& Robertson (2018 in press). Job search information seeking behaviours: an ego-net study of networking amongst young job-seekers. Journal of Librarianship and Information Science.

Ross has nineteen contacts in his JSIN (Figure 5). As evidenced by the proportion of out-degree contacts (89\%), he was a very active networker during job search. His conscientious attitude was also apparent in the organised nature of his search for an internship. He said, "I'm mainly researching jobs in the industry I want to go into. So that's looking at Twitter, and that. You know, specific games Twitter accounts." As shown in Table 6, he accrued a wealth of job search information from these sites (i.e. 'GD Twitter 1-10'). Two of them were also linked to discussion forums where company figureheads would "post videos and that saying 'this is what we're looking for in certain people [job applicants]"'. Other members of the public would also use the forums, and he said, "If I have a specific question [about job search] I'll just shoot it out there".

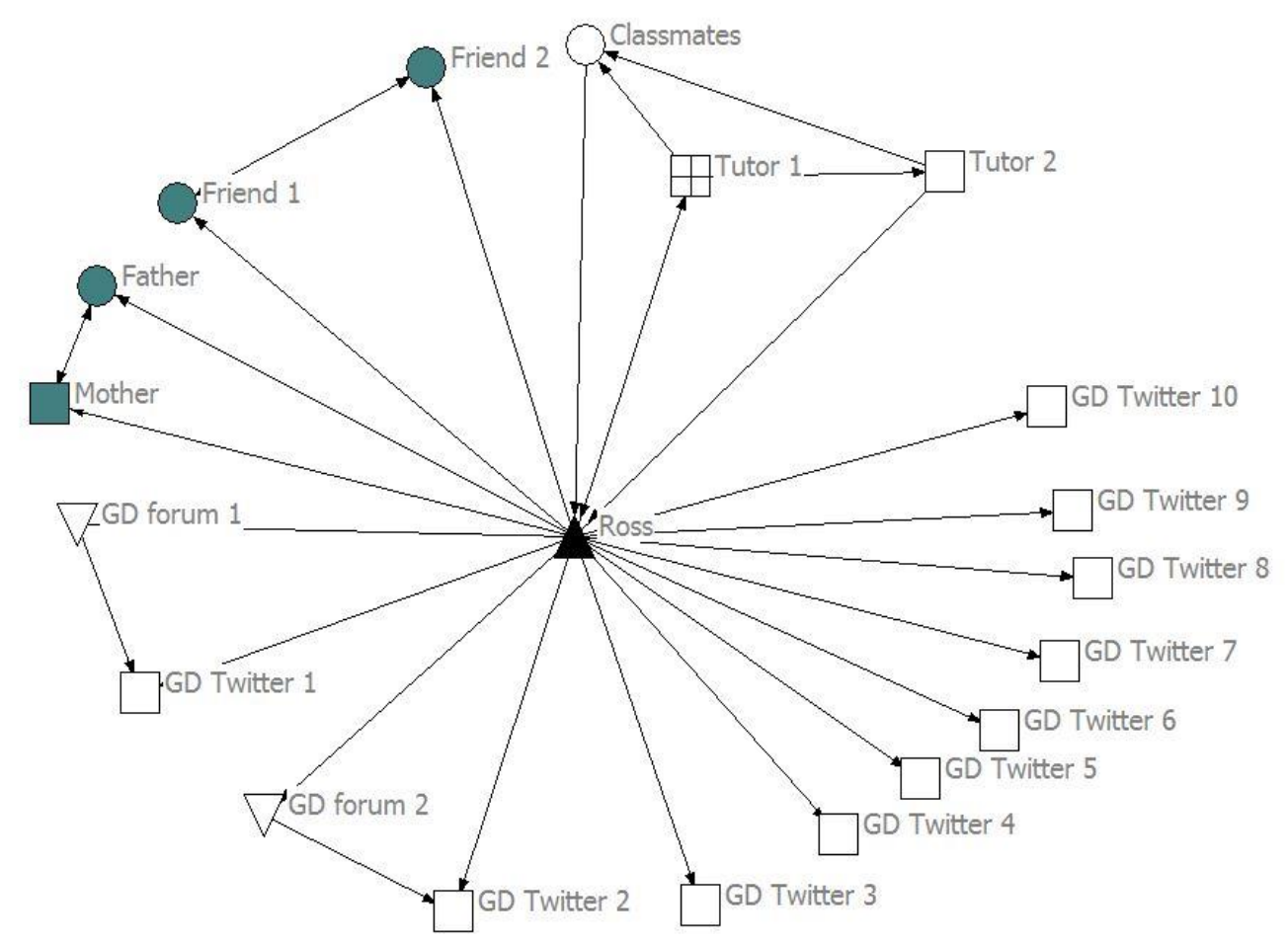

Figure 5 Ross's job search information network

Ross sourced job information from the Facebook group page run by his college tutors, one of whom he had also approached in the classroom environment for advice about finding a job in the industry. He had also approached family contacts by "pulling them to the side" when he needed help with his CV and applications. A full typology of contacts and information contained within Ross's JSIN is presented in Table 7. 
Mowbray, Hall, Raeside \& Robertson (2018 in press). Job search information seeking behaviours: an ego-net study of networking amongst young job-seekers. Journal of Librarianship and Information Science.

\begin{tabular}{|l|l|l|}
\hline Network & Contact type & $\begin{array}{l}\text { Type of information provided } \\
\text { (by no. of contacts) }\end{array}$ \\
\hline Formal Individual & $\begin{array}{l}\text { Tutor, 2 } \\
\text { Industry and business } \\
\frac{\text { representatives: GD forum 1, GD }}{\text { forum 2 }}\end{array}$ & $\begin{array}{l}\text { Industry/role-related (4) } \\
\text { Practical skills (3) } \\
\text { Job opportunities (4) }\end{array}$ \\
\hline Formal organisation & $\begin{array}{l}\text { Industry and company: GD } \\
\text { Twitter 1, GD Twitter 2, GD } \\
\text { Twitter 3, GD Twitter 4, GD } \\
\text { Twitter 5, GD Twitter 6, GD } \\
\text { Twitter 7, GD Twitter 8, GD } \\
\text { Twitter 9, GD Twitter 10 }\end{array}$ & $\begin{array}{l}\text { Practical skills (10) } \\
\text { Contacts/leads (2) } \\
\text { Job opportunities (10) }\end{array}$ \\
\hline Informal & $\begin{array}{l}\text { Immediate family: Dad, Mum } \\
\text { Extended family, friends, and } \\
\text { classmates: Friend 1, Friend 2, } \\
\text { Classmates } \\
\text { Other informal: Games forum 1, } \\
\text { Games forum 2 }\end{array}$ & $\begin{array}{l}\text { Practical skills (2) } \\
\text { Job opportunities (2) }\end{array}$ \\
\hline
\end{tabular}

Table 7 Analysis of Ross's JSIN

Steve's job search information network

Steve was in the same college Ross. He lived at home with his mother, and had been job searching for three months, albeit "not every day". He had no clear job goal in mind. He admitted that he would "probably just do anything": his motivation to work was simply to make some money during the summer. As shown in Figure 6, his JSIN is small, displaying only four contacts, with no out-degree contacts. Notably, three of these are social media contacts, representing his college class Facebook page, where "our tutors usually put up some job listings if there are any in our area or anything to do with our industry". 


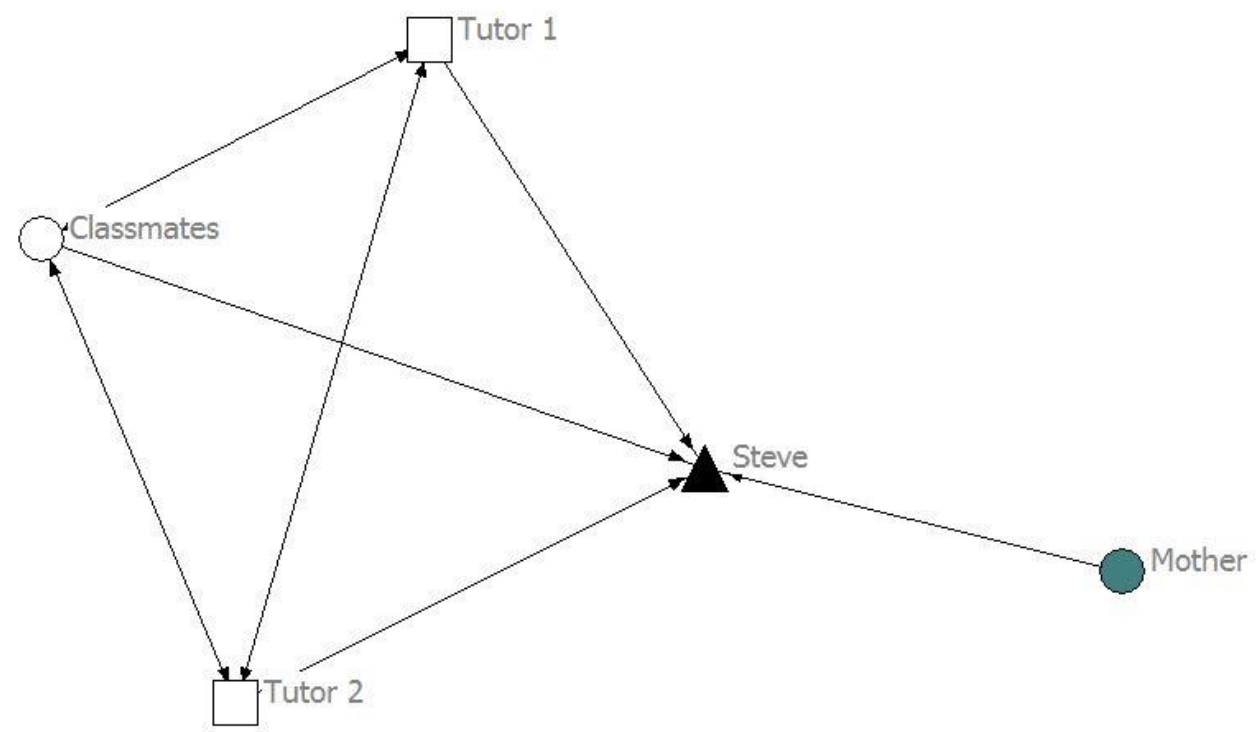

Figure 6 Steve's job search information network

Steve's mother was also prominent in his JSIN. He said, "My mum looked at some jobs for me, and she sometimes points me in certain directions on job. I think she uses a job search engine". A full typology of contacts and information contained within Steve's JSIN is presented in Table 8.

\begin{tabular}{|l|l|l|}
\hline Nature of contact & Contact type & $\begin{array}{l}\text { Type of information provided } \\
\text { (by no. of contacts) }\end{array}$ \\
\hline Formal Individual & $\frac{\text { Teachers and tutors: Tutor 1, }}{\text { Tutor 2 }}$ & $\begin{array}{l}\text { Industry/role-related (2) } \\
\text { Job opportunities (2) }\end{array}$ \\
\hline Informal & $\begin{array}{l}\text { Immediate family: Mother } \\
\frac{\text { Extended family, friends, and }}{\text { classmates: Classmates }}\end{array}$ & $\begin{array}{l}\text { Industry/role-related (1) } \\
\text { Practical skills (1) } \\
\text { Job opportunities (1) }\end{array}$ \\
\hline
\end{tabular}

Table 8 Analysis of Steve's JSIN 
Mowbray, Hall, Raeside \& Robertson (2018 in press). Job search information seeking behaviours: an ego-net study of networking amongst young job-seekers. Journal of Librarianship and Information Science.

\section{Simon's job search information network}

Simon had recently gained employment as an electrical engineer, having completed an MSc in a related discipline. His job search lasted six months, during which time he lived at home with his parents. He stated that his main motivation for finding work was a desire to leave his casual, part-time occupation:

"There was a few people older than me who I'd seen graduate and continue to work in these kinds of places, so I was just like, I don't want to do that. I mean I wanted a job in the field obviously, but that was probably the biggest driver for me".

Simon's JSIN shows eleven contacts, a high proportion of which are out-degree contacts (82\%). As shown in Figure 7, Simon had acquired job search information from two distinct groups of contacts. One was a formal group that included lecturers from his university course. He explained how he "managed to get in" with the lecturers by volunteering to work with them on summer placements in the department. When he applied for the company where he became employed, his lecturer, who knew the manager (i.e. Current employer), "put in a word" for him.

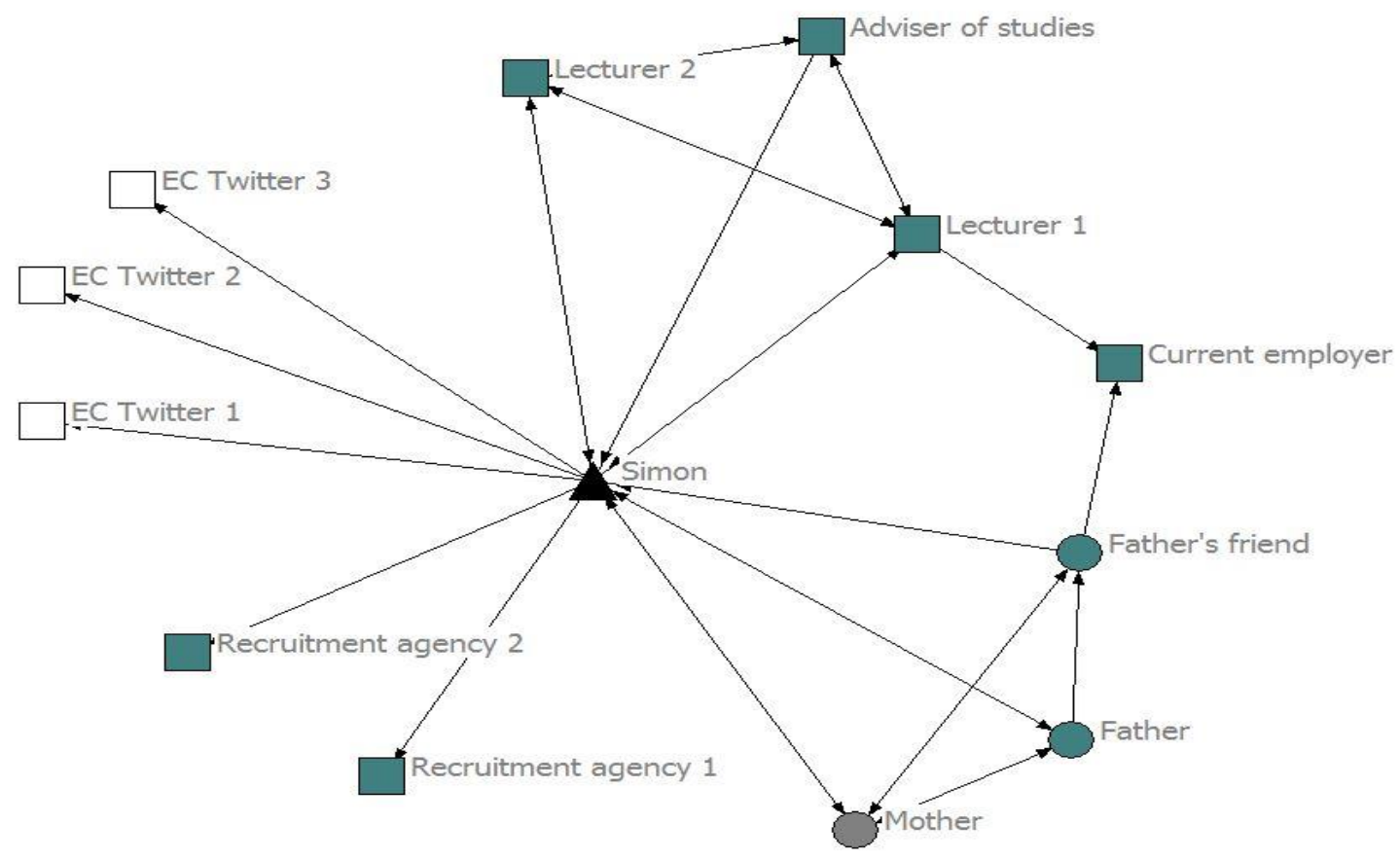

Figure 7 Simon's job search information network

The informal group of contacts in Simon's JSIN includes his "Dad's friend", who worked for an industry body in his target sector. In addition to providing him with useful 
Mowbray, Hall, Raeside \& Robertson (2018 in press). Job search information seeking behaviours: an ego-net study of networking amongst young job-seekers. Journal of Librarianship and Information Science.

industry information, this contact had also "definitely spoken to the manager" about his successful job application. It is notable that Simon also had three social media contacts, all of which were companies in his targeted industry. He used Twitter for research, and said, "I've found social media is quite a good way to see, especially engineering companies, to see what their latest projects and stuff are". A full typology of contacts and information contained within Simon's JSIN is presented in Table 9.

\begin{tabular}{|c|c|c|}
\hline Nature of contact & Contact type & $\begin{array}{l}\text { Type of information provided } \\
\text { (by no. of contacts) }\end{array}$ \\
\hline Formal Individual & $\begin{array}{l}\text { Teachers and tutors: Lecturer } 1 \\
\text { Lecturer } 2, \text { Adviser of studies }\end{array}$ & $\begin{array}{l}\text { Industry/role-related (2) } \\
\text { Practical skills (1) } \\
\text { Contacts/leads (2) } \\
\text { Job opportunities (2) }\end{array}$ \\
\hline Formal organisation & $\begin{array}{l}\text { Private bodies and quangos: } \\
\text { Recruitment agency 1, } \\
\text { Recruitment agency } 2 \\
\text { Industry and company: EC } \\
\text { Twitter 1, EC Twitter 2, EC } \\
\text { Twitter } 3\end{array}$ & $\begin{array}{l}\text { Industry/role-related (3) } \\
\text { Contacts/leads (3) } \\
\text { Job opportunities (2) }\end{array}$ \\
\hline Informal & $\begin{array}{l}\text { Immediate family: Father, Mother } \\
\text { Other informal: Dad's friend }\end{array}$ & $\begin{array}{l}\text { Industry/role related (1) } \\
\text { Practical skills (3) } \\
\text { Contacts/leads (1) } \\
\text { Job opportunities (1) }\end{array}$ \\
\hline
\end{tabular}

Table 9 Analysis of Simon's JSIN

\section{Suzanne's job search information network}

At the time of interview Suzanne was employed on a short-term contract as a researcher in the media industry. She had been job searching for around one month, during which time she found her latest job, and had continued to look for a new contract within the same field. She was motivated to find similar work because she was qualified as a researcher and found work in the media industry to be intellectually stimulating. She compared it favourably with work in previous part-time and casual roles: "I don't think I 
Mowbray, Hall, Raeside \& Robertson (2018 in press). Job search information seeking behaviours: an ego-net study of networking amongst young job-seekers. Journal of Librarianship and Information Science.

could ever do that again, knowing that I've done it for so long. The job I'm doing just now researching films is great because you get to get lost in a different world".

Suzanne's JSIN shows nine contacts (see Figure 8). All are out-degree, thus indicating active networking. Figure 8 illustrates how the contacts in her previous job (e.g. 'Ex colleague 1') were connected to her newest colleagues (e.g. 'Colleague 3'), via a social media contact called 'FB group admin', who operates a Facebook group page for people employed within the media industry in Scotland. Suzanne described how she came to be aware of this page, by speaking to one of her ex colleagues:

"I was the one who talked to her about looking for work. And, I was telling her my whole history. Basically, careers in the media. And one thing I think it is quite useful to do (...) is having this conversation about me looking for work, and telling them what other people have done to help me, and who else I've spoken to. And that prompts them to also help you".

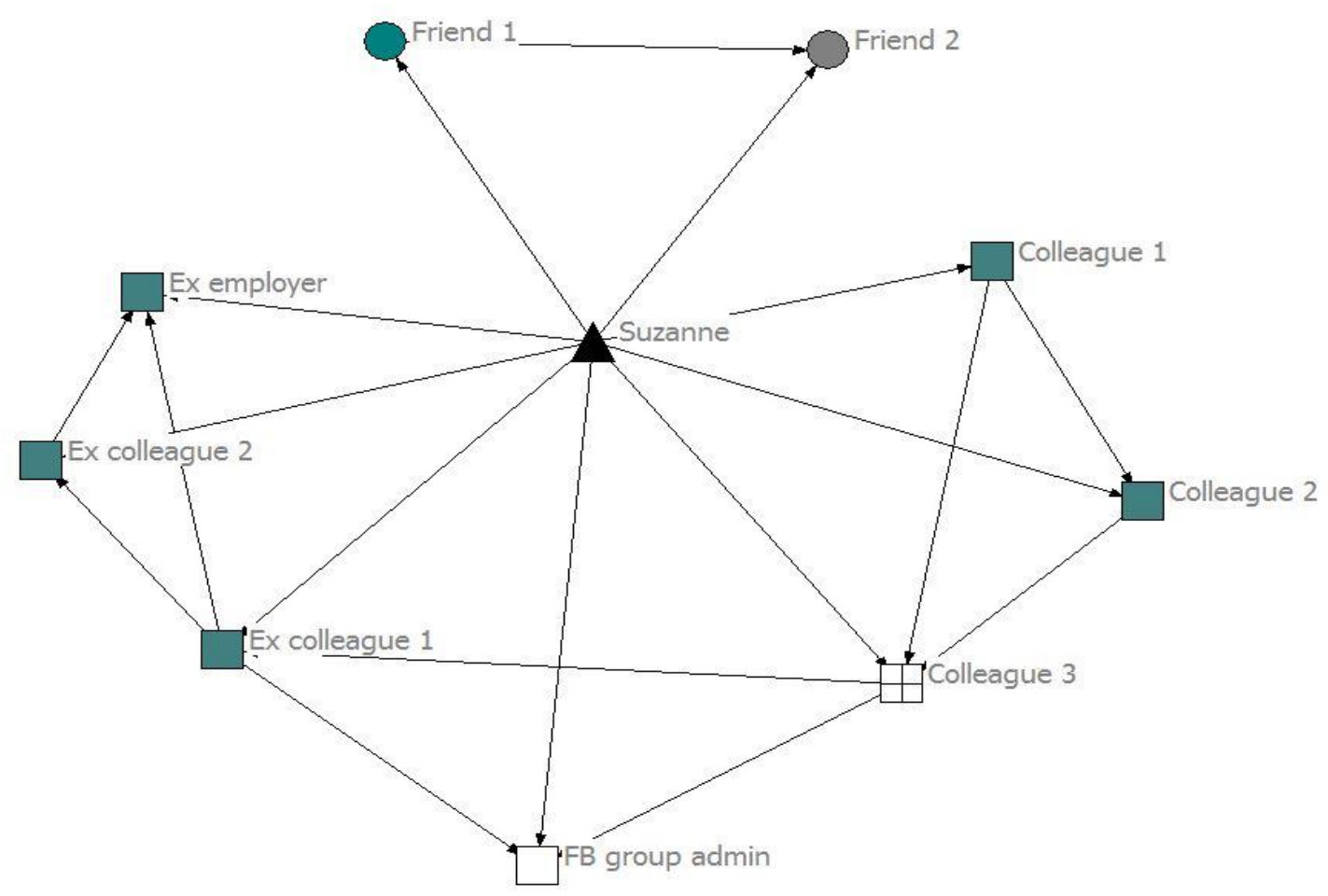

Figure 8 Suzanne's job search information network

The colleague told Suzanne about the Facebook group, and began sending her text messages with screenshots of job vacancies from the group page. Suzanne then decided to set up a Facebook account to access these postings directly. This is where she found out about the new job. Suzanne gave many examples of approaching colleagues and contacting friends to ask for application assistance and about possible job opportunities. 
Mowbray, Hall, Raeside \& Robertson (2018 in press). Job search information seeking behaviours: an ego-net study of networking amongst young job-seekers. Journal of Librarianship and Information Science.

A full typology of contacts and information contained within Suzanne's JSIN is presented in Table 10.

\begin{tabular}{|c|c|c|}
\hline Nature of contact & Contact type & $\begin{array}{l}\text { Type of information provided } \\
\text { (by no. of contacts) }\end{array}$ \\
\hline Formal Individual & $\begin{array}{l}\text { Work contacts: Colleague } 1, \\
\text { Colleague 2, Colleague } 3, \text { Ex } \\
\text { colleague 1, Ex colleague } 2 \\
\text { Industry and company } \\
\text { representatives: FB group admin }\end{array}$ & $\begin{array}{l}\text { Practical skills (2) } \\
\text { Contacts/leads (2) } \\
\text { Job opportunities (5) }\end{array}$ \\
\hline Formal organisation & $\begin{array}{l}\text { Industry and company: Ex } \\
\text { employer }\end{array}$ & Job opportunities (1) \\
\hline Informal & $\begin{array}{l}\text { Extended family, friends, and } \\
\text { classmates: Friend 1, friend } 2\end{array}$ & Practical skills (2) \\
\hline
\end{tabular}

Table 10 Analysis of Suzanne's JSIN

\section{Intervening variables identified in the interview data}

Wilson's model (Figure 1) indicates that individuals who experience information needs can meet with intervening variables. These either enable or act as barriers to information seeking. Three main types of intervening variables related to job search networking were identified in the interviews with the seven individuals discussed above. An analysis of these are outlined below as (i) situational, (ii) social and (iii) intrapersonal factors.

\section{Situational factors}

The situation of the interview participants directed much of their job search networking behaviours. This suggests that the proximity of network contacts is a key enabler of information seeking. Indeed, the unemployed respondents who had left school without entering employment, education, or training, networked with public and charity organisations. Meanwhile the students networked with lecturers and classmates, and the one participant who was in employment networked with co-workers. It has been shown above that family members are often present in the JSINs, particularly the parents of jobseekers. 
The ascribed nature of situational contacts can have an impact on the quality and/or diversity of information acquired through networking. This is closely linked with social factors, and specific examples are presented in subsequent sections of this paper. However, situational factors could also be a direct barrier to job search networking. The extreme case of Ashley, for example, reveals that she suffered from a limited availability of strong contacts, having lost touch with her family. Living in a hostel also meant that she had limited access to the Internet. This prevented her from using social media on a regular basis and developing her online network. Craig also had limited access, with no Internet access on his phone.

\section{Social factors}

Social factors, particularly the resourcefulness of contacts, are also shown to enable job search networking in this study. For example, Simon noted how "in terms of searching, the [university] department [has] pretty good industry links". He explained the benefit of this to identifying possible employers (to "find all the [hiring] companies by myself") and making approaches to them ("I would mention to a lecturer...and then you'd sort of get put in touch with those people"). Ashley and Michael were also keen to expound the usefulness of their support workers and careers advisers in providing indepth information and support relating to job search, and the approachability of such network contacts. The presence of friends on social media platforms is also an indirect enabler of job search networking online. For example, both Ross and Michael stated that they used these platforms mainly to interact with friends, yet would consume job search information at the same time. This might be achieved passively or through active searching.

In some instances the resourcefulness of contacts is also a barrier to job search networking. For example, Simon said that he stopped visiting his director of studies at university, describing him as "useless" at giving job search advice. Similarly Suzanne claimed that her parents would not be able to help her because they had no industry knowledge. She explained: "They were teachers (...) so it's not like they would know".

\section{Intrapersonal factors}

Having an awareness of networking benefits is evident in this study as an enabler of job search networking behaviours. For example, Suzanne stated that the only way to find a job in her industry was by knowing who to ask, and Michael demonstrated an awareness of networking benefits within his local labour market when he said "a lot of local firms, especially on the mechanical side, they won't put out an ad", and explained that he found it better just "going up and asking". Both of these participants also indicated that their use of social media platforms during job search was simply due to their awareness that it could be used for that purpose. Michael said "believe it or not I never really thought about it till they [Skills Development Scotland] mentioned it to us... So yeah, it was because of them that I started looking there". Suzanne said: 
"I don't really do Facebook. I don't really do social media. I only got Facebook to get [access to a group]. It's not something I've done because I never knew about it. I never knew about the Facebook thing because I never had a Facebook".

It is notable that in the cases of both Suzanne and Michael, awareness led to use. This, in turn, led to a positive attitude towards social media as a networking platform. Although Suzanne articulated her general ambivalence towards social media, she conceded "This way is the future of getting jobs because it is people genuinely looking for people other than the council having to legally post a job". In contrast, Steve had no awareness of how he could potentially use Twitter to network with companies in his industry, and was dismissive of the platform, saying "Nah, nah, nah, nah. I'm not that bothered about Twitter".

Comfort in approaching contacts and willingness to open a job search dialogue are also seen to be enablers and barriers to job search networking here. Michael, for example, stated that speaking to people was "no problem at all", and that it "happens quite frequently in my day-to-day life". Indeed, speaking about it to his friends' parents led to their sending him job postings on social media. Craig and Steve were more ambivalent: Craig said "it depends who it is" and Steve noted "I wouldn't actively ask people". Simon was of a similar opinion. Of asking people for help he explained:

"I don't know to be honest. I'm quite a quiet guy. I'm probably not the most outgoing of people. I would probably force myself to, I guess. I would certainly try to open a dialogue with somebody, if I knew they were in a position help. I would definitely try and speak to them about it".

\section{Discussion}

Wilson's (1981) theory postulates that it is crucial to understand the context within which information needs develop in order to devise innovative solutions for information practitioners. The results presented in this paper give much credence to this view in respect of job search networking. A key finding is the participants' motivations (i.e. intrapersonal context) for finding a job. Motivation had at least an indirect impact on the size and diversity of the interviewees' JSINs. This applies to Craig and Steve, whose small networks and limited active attempts at networking was as apparent as their inability to articulate a clear job goal or convincing motivation for finding work. This finding adds to prior research which indicates that identification of a goal and the development of a career identity are crucial starting points in job search. This is because these two factors enable the planning of goal pursuit (McArdle et al., 2007: 249; Van Hooft., 2013). Lacking suitable impetus, here Craig and Steve appear to have applied less effort and intensity- both of which are closely linked with positive employment outcomes (Saks, 2005; Wanberg, 2012) - in their job search.

Demographic and situational factors also have a notable bearing on the participants' job search networking behaviour. For example, Ashley and Michael were 
both seventeen, not in employment, and had no work experience that was directly relevant to their targeted job roles. This is reflected in their JSINs, which show that they had to create ties to people in these roles (e.g. Ashley with the community centre manager and Michael with local businesses) to gain direct access to industry or role related information. Along with Steve, these young jobseekers were heavily reliant on government-funded careers professionals who were instrumental in helping them to build such informational contacts, by providing leads or raising awareness about the effectiveness of job search networking. They also demonstrate the importance of such professionals as crucial sources of social capital for young people who face barriers to the labour market. In contrast, Simon and Suzanne were both approaching their mid-twenties, were more qualified/experienced, and had contacts with direct ties to their targeted job roles (e.g. Simon's lecturers with whom he had worked, and Suzanne's work colleagues). This suggests that even within the 16-24 age-group, age, education level, employment status, and work experience could all be critical to the direction and nature of job search networking. It also provides further evidence to suggest that mobility is self-generating during job search, with work experience providing access to a widening pool of weaker network contacts, as identified by Granovetter (1995: 85).

Treating job search networking as an information behaviour, the findings related here reveal that job-seekers acquire a number of different information types from a range of network contacts. This finding adds a further dimension to prior research where the role of information in employment outcomes has been assumed (De Graaf and Flap, 1988; Gayen et al., 2010; Lin et al., 1981; Macmillan et al., 2015; Russell, 1999), or where the focus has been on information exchanges which lead directly to employment (Granovetter, 1974; Franzen and Hangartner, 2006). The findings also show that job search networking can be both active and passive in nature, and that the quantity of information received can vary substantially per job-seeker (see Tables 3-9). Combined, these factors are important in explaining the informational role of networks during job search. For example, it is a reasonable assumption that receiving a higher quantity of information from a diverse range of contacts will have a positive bearing on job search products (e.g. applications, CVs) and outcomes (e.g. securing interviews). However, attention needs also to be paid to the veracity of information received during these exchanges. As noted above, the participants in this study relied to a large extent on ascribed or easily accessible contacts. This is likely to have been affected by the unequal distribution of social capital resources within network structures, as has been previously discussed by Lin (1999: 41).

Analysis of the JSINs shows that for many of the participants, a key challenge of job search networking was sourcing information from contacts who could provide insightful information about specific industries. Whilst their role was unevenly distributed between the participants, the multifunctional nature of social media platforms (El Ouiridi et al., 2014; Kietzmann et al., 2011) such as Facebook and Twitter proffered the participants valuable access to weaker network contacts and novel industry information. For example, Ross and Simon could use Twitter to gather information from potential employers within their target industries, and Facebook groups provided platforms for Ross, Steve and Suzanne to gather and share job information with 
institutional, informal, and industry contacts. These examples give a clear indication of the potentially profound role social media platforms have on job search networking as an information behaviour. Similarly to other contexts (Foster, 2005; Meho and Tibbo, 2003). This shows how social media could be a crucial aid to networking as an information seeking behaviour during job search. However, it is notable those interviewed for this study faced some very distinct intrapersonal or situational barriers to using these platforms. In some instances this was related to attitudes or awareness (e.g. Steve and Suzanne), which could be overcome easily with the appropriate guidance. However, for others (e.g. Ashley with no Internet access where she lived, and Craig with no Internet access on his mobile phone) the issues were tangible, and would need require significant interventions to ameliorate.

\section{Conclusion}

The findings presented in this paper have provided a micro-level understanding of job search networking and its antecedents. By applying an ego-centric approach, this work has determined the nature of the contacts young job-seekers engage with during job search, and the types of information acquired in such exchanges. Additionally, it has been possible to identify the role of social media platforms as tools for networking, and the affordances they bring in terms of access to weak ties and novel information. Crucially, it has been demonstrated that network contacts have a key informational role throughout job search, and this extends beyond the simple diffusion of information about job openings. For young people who are unemployed, it has been shown that governmentfunded professionals are particularly prominent in this regard. Indeed, in addition to linking jobseekers to important contacts, they can also raise awareness about networking as a job search behaviour. Such knowledge is key to understanding the operational role of social capital, which is associated with early success in the labour market (Caspi et al., 1998; Kramarz and Skans, 2014).

Significantly, by using Wilson's $(1981 ; 1997)$ theory to underpin the design and analysis of the research, the vital influence of context and needs on networking is also apparent. Indeed, the context of the job-seekers interviewed here had a notable impact on the extent and nature of their JSINs, and was often traceable to intervening variables which either enabled or acted as a barriers to job search networking. Therefore, to create tailored policy interventions for young job-seekers which involve networking and the use of social media, it is necessary to understand a range of other factors that include job search goals, employment status, work experience, perceptions and attitudes.

Further research is currently in progress to determine the prevalence and outcomes of behaviours evident in the study reported here. By testing the variables identified above using a much larger sample of young job-seekers more will be learnt about the processes of job search networking and its various antecedents, and how this may be applied in policy. Further publications associated with this study will address these issues, and other broader themes related to the concept of job search networking. As well as providing valuable insight into the information behaviours of young job-seekers, 
Mowbray, Hall, Raeside \& Robertson (2018 in press). Job search information seeking behaviours: an ego-net study of networking amongst young job-seekers. Journal of Librarianship and Information Science.

for application in policy development at the level of national skills agencies, such work demonstrates the utility of studying job search from an information perspective. It also reveals that consideration of information behaviour around job search is a fruitful subject of investigation for the Information Science community. 
Mowbray, Hall, Raeside \& Robertson (2018 in press). Job search information seeking behaviours: an ego-net study of networking amongst young job-seekers. Journal of Librarianship and Information Science.

\section{References}

Adecco Group (2014) \#Socialrecruiting a global study: Job search, digital reputation, and HR practices in the social media age. Available at: http://www.adecco.com/enUS/Industry-Insights/Documents/social-recruiting/adecco-global-social-recruitingsurvey-global-report.pdf (Accessed 10th September 2017).

Alam A, Khusro S, Ullah I and Karim MS (2017) Confluence of social network, social question and answering community, and user reputation model for information seeking and experts generation. Journal of Information Science. 43(2): 260-274.

Artess J, Mellors-Bourne R and Hooley T (2017) Employability: a review of the literature. Report, Higher Education Academy, UK.

Barriball LK and While A (1994) Collecting Data using a semi-structured interview: a discussion paper. Journal of Advanced Nursing. 19(2): 328-335.

Bian Y (1997) Bringing strong ties back in: Indirect ties, network bridges, and job searches in China. American Sociological Review 62 (3): 366-385.

Borgatti SP, Everett MG and Freeman LC (2002) Ucinet for Windows: Software for Social Network Analysis. Analytic Technologies Harvard: MA

Caspi A, Wright BRE, Moffitt TE, and Silva PA (1998) Early failure in the labor market: Childhood and adolescent predictors of unemployment in the transition to adulthood. American Sociological Review 63(3): 424-451.

Cooke L and Hall H (2013) Facets of DREaM: a social network analysis examining network development in the UK LIS research community. Journal of Documentation 69(6): 786-806. 
Mowbray, Hall, Raeside \& Robertson (2018 in press). Job search information seeking behaviours: an ego-net study of networking amongst young job-seekers. Journal of Librarianship and Information Science.

Creswell J W and Plano-Clark VL (2007) Choosing a mixed methods design. In:

Creswell JW and Plano-Clark VL (eds), Designing and conducting mixed methods research. London: Sage, pp. 53-106.

De Graaf ND and Flap HD (1988) "With a little help from my friends": Social resources as an explanation of occupational status and income in West Germany, The Netherlands, and the United States. Social Forces 67(2): 452-472.

El Ouirdi M, El Ouirdi A, Segers J and Henderickx E (2014) Social media conceptualization and taxonomy: a Lasswellian framework. Journal of Creative Communications, 9(2): 107-126.

Ellison NB, Steinfield C and Lampe C. (2007) The benefits of Facebook "friends:" Social capital and college students' use of online social network sites. Journal of ComputerMediated Communication 12(4): 1143-1168.

Foster A, and Ford N (2003) Serendipity and information seeking: an empirical study. Journal of Documentation, 59(3): 321-340.

Franzen A and Hangartner D (2006) Social networks and labour market outcomes: The non-monetary benefits of social capital. European Sociological Review 22(4): 353368.

Gayen K, McQuaid R, and Raeside R (2010) Social networks, age cohorts and employment. International Journal of Sociology and Social Policy 30(5/6): 219-238.

Granovetter MS (1973) The strength of weak ties. American journal of sociology 78(6): 1360-1380.

Granovetter MS (1983) The strength of weak ties: A network theory revisited. Sociological Theory 1(1): 201-233. 
Mowbray, Hall, Raeside \& Robertson (2018 in press). Job search information seeking behaviours: an ego-net study of networking amongst young job-seekers. Journal of Librarianship and Information

Science.

Granovetter MS (1995) Getting a job: A study of contacts and careers. University of Chicago Press: Chicago.

Hooley T, Hutchinson J and Watts AG (2010) Careering through the web: the potential of Web 2.0 and 3.0 technologies for career development and career support services. Report, UK Commission for Employment and Skills, UK, June.

Hooley T (2012) How the internet changed career: framing the relationship between career development and online technologies. Journal of the National Institute for Career Education and Counselling 29(1): 3-12.

Hosseini-Pozveh M, Zamanifar K and Naghsh-Nilchi AR (2016) A community-based approach to identify the most influential nodes in social networks. Journal of Information Science 43(2): 204-220.

Hsieh HF and Shannon SE (2005) Three approaches to qualitative content analysis. Qualitative Health Research 15(9): 1277-1288.

Huberman BA, Romero DM and Wu F (2009) Crowdsourcing, attention and productivity. Journal of Information Science 35(6): 758-765.

Huffman ML and Torres L (2001) Job search methods: Consequences for gender-based earnings inequality. Journal of Vocational Behavior 58(1): 127-141.

Hughes DJ, Rowe M, Batey M and Lee A (2012) A tale of two sites: Twitter vs. Facebook and the personality predictors of social media usage. Computers in Human Behavior 28(2): 561-569.

Kietzmann JH, Hermkens K, McCarthy IP and Silvestre BS (2011) Social media? Get serious! Understanding the functional building blocks of social media. Business Horizons 54(3): 241-251. 
Mowbray, Hall, Raeside \& Robertson (2018 in press). Job search information seeking behaviours: an ego-net study of networking amongst young job-seekers. Journal of Librarianship and Information Science.

Kramarz F and Skans ON (2014) When strong ties are strong: Networks and youth labour market entry. The Review of Economic Studies 81(3): 1164-1200.

Kwak H, Lee C, Park H and Moon S (2010) What is Twitter, a social network or a news media? In: Proceedings of the 19th international conference on World Wide Web Raleigh, North Carolina, USA, 26-30 April 2010, pp. 591-600. New York: ACM.

Lambert TA, Eby LT and Reeves MP (2006) Predictors of networking intensity and network quality among white-collar job seekers. Journal of Career Development 32(4): 351-365.

Lin N, Ensel WM, and Vaughn JC (1981) Social resources and strength of ties: Structural factors in occupational status attainment. American Sociological Review 46(4): 393405.

Lin N (1999) Building a network theory of social capital. Connections 22(1): 28-51.

Lin N (2002) Social capital: A theory of social structure and action. Cambridge university press: Cambridge.

Lin N (2008) A Network Theory of Social Capital. In: Castiglione D, Van Deth J and Wolleb G (eds). The Handbook of Social Capital New York: Oxford University Press, pp.50-69.

Longridge D N and Hooley T (2012) An experiment in blended career development: the University of Derby's social media internship programme. Journal of the National Institute for Career Education and Counselling 29: 1-46.

Mann A (2012) It's who you meet: why employer contacts at school make a difference to the employment prospects of young adults. Report, Education and Employers Taskforce, UK, February. 
Mowbray, Hall, Raeside \& Robertson (2018 in press). Job search information seeking behaviours: an ego-net study of networking amongst young job-seekers. Journal of Librarianship and Information Science.

Manroop L, and Richardson J (2016) Job search: A multidisciplinary review and research agenda. International Journal of Management Reviews 18(2): 206-227.

Macmillan L, Tyler C and Vignoles A (2015) Who gets the top jobs? The role of family background and networks in recent graduates' access to high-status professions. Journal of Social Policy 44(3): 487-515.

McArdle S, Waters L, Briscoe JP, and Hall DTT (2007) Employability during unemployment: Adaptability, career identity and human and social capital. Journal of vocational behavior 71(2): 247-264.

McQuaid RW, and Lindsay C (2005) The concept of employability. Urban Studies 42(2): 197-219.

Meho LI, and Tibbo HR (2003) Modeling the information-seeking behavior of social scientists: Ellis's study revisited. Journal of the American Society for Information Science and Technology 54(6): 570-587.

Mo R and Leung L (2015) Exploring the roles of narcissism, uses of, and gratifications from microblogs on affinity-seeking and social capital. Asian Journal of Social Psychology 18(2): 152-162.

Palys T (2008) Purposive sampling. In: Given LM (ed) The Sage encyclopedia of qualitative research methods. Sage: Los Angeles, pp. 697-8.

Papakonstantinidis S (2014) Social recruiting: exploring the impact of social networking sites on digital natives' occupational opportunities. PhD Thesis, University of Leicester, UK.

Robins G (2015) Doing social network research. London: Sage Publications.

Russell H (1999) Friends in low places: gender, unemployment and sociability. Work, Employment \& Society 13(2): 205-224. 
Mowbray, Hall, Raeside \& Robertson (2018 in press). Job search information seeking behaviours: an ego-net study of networking amongst young job-seekers. Journal of Librarianship and Information Science.

Rutten M, Ros A, Kuijpers M and Kreijns K (2016) Usefulness of social network sites for adolescents' development of online career skills. Journal of Educational Technology \& Society 19(4): 140-150.

Saks AM (2005) Job search success: A review and integration of the predictors, behaviors, and outcomes Career Development and Counseling: Putting theory and research to work 16(3): 155-179.

Schultz-Jones B (2009) Examining information behavior through social networks: an interdisciplinary review. Journal of Documentation 65(4): 592-631.

Schwab DP, Rynes SL and Aldag RJ (1987) Theories and research on job search and choice. Research in Personnel and Human Resources Management 5(1): 129-166.

Scottish Government (2017) Destinations of school leavers. Available at: http://www.gov.scot/Topics/Statistics/Browse/School-Education/TrendDestinations (accessed 8th September 2017).

Seibert SE, Kraimer ML and Liden RC (2001) A social capital theory of career success. Academy of Management 44(2): 219-137.

Skills Development Scotland (2012) Career management skills framework for Scotland. Available at: https://cica.org.au/wpcontent/uploads/career_management_skills_framework_scotland.pdf (accessed 11 September 2017).

Tian FF and Lin N (2016) Weak ties, strong ties, and job mobility in urban China: 19782008. Social Networks 44(11): 117-129.

Valenzuela S, Park N and Kee K F (2009) Is there social capital in a social network site? Facebook Use and College Students' Life Satisfaction, Trust, and Participation. Journal of Computer-Mediated Communication 14(4): 875-901. 
Mowbray, Hall, Raeside \& Robertson (2018 in press). Job search information seeking behaviours: an ego-net study of networking amongst young job-seekers. Journal of Librarianship and Information Science.

Van Hooft E A, Wanberg CR and Van Hoye G (2013) Moving beyond job search quantity: Towards a conceptualization and self-regulatory framework of job search quality. Organizational Psychology Review 3(1): 3-40.

Van Hoye G, Hooft EA and Lievens F (2009) Networking as a job search behaviour: A social network perspective. Journal of Occupational and Organizational Psychology 82(3): 661-682.

Van Hoye G, Klehe IU and van Hooft EAJ (2013) Job search behavior as a multidimensional construct: a review of different job search behaviors and sources. In: Klehe UC and van Hooft EAJ (eds), Oxford Handbook of Job Loss and Job Search. New York: Oxford University Press, pp.1-43.

Wanberg CR (2012) The individual experience of unemployment. Annual Review of Psychology 63(15): 369-396.

Wanberg CR, Kanfer R and Banas JT (2000) Predictors and outcomes of networking intensity among unemployed job seekers. Journal of Applied Psychology 85(4): 491503.

Wasserman S and Faust K (1994). Social network analysis: Methods and applications. Cambridge university press: Cambridge.

Wilson TD (1981) On user studies and information needs. Journal of Documentation 37(1): 3-15.

Wilson TD (1997) Information behaviour: an interdisciplinary perspective. Information Processing \& Management 33(4): 551-572.

Wilson TD (1999) Models in information behaviour research. Journal of Documentation 55(3): 249-270. 
Mowbray, Hall, Raeside \& Robertson (2018 in press). Job search information seeking behaviours: an ego-net study of networking amongst young job-seekers. Journal of Librarianship and Information Science.

Yakubovich V (2005) Weak ties, information, and influence: How workers find jobs in a local Russian labor market. American Sociological Review 70(3): 408-421.

i i Participants were recruited from a third sector employability group, the national careers service, and Further/Higher Education institutions. This was achieved by contacting support workers, careers advisers, and lecturers at the associated organisations. These individuals gave permission to conduct the interviews, and helped to organise them.

ii A pseudonym was allocated to each participant to protect their identities. 